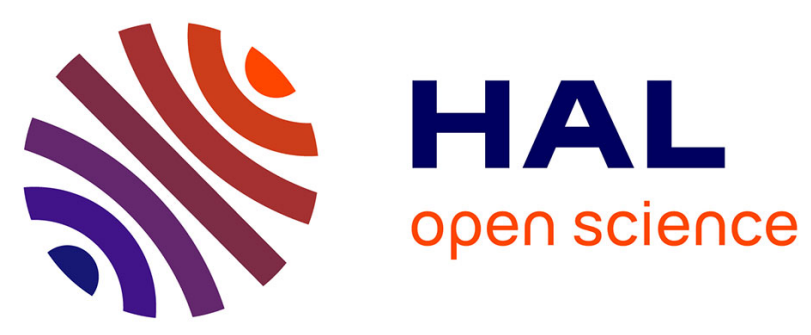

\title{
Temporal evolution of atrazine and metolachlor concentrations exported in runoff and subsurface water with vegetated filter strips
}

Caron, Lafrance, Auclair

\section{- To cite this version:}

Caron, Lafrance, Auclair. Temporal evolution of atrazine and metolachlor concentrations exported in runoff and subsurface water with vegetated filter strips. Agronomy for Sustainable Development, 2012, 32 (4), pp.935-943. 10.1007/s13593-012-0087-8 . hal-00930566

\section{HAL Id: hal-00930566 https://hal.science/hal-00930566}

Submitted on 1 Jan 2012

HAL is a multi-disciplinary open access archive for the deposit and dissemination of scientific research documents, whether they are published or not. The documents may come from teaching and research institutions in France or abroad, or from public or private research centers.
L'archive ouverte pluridisciplinaire HAL, est destinée au dépôt et à la diffusion de documents scientifiques de niveau recherche, publiés ou non, émanant des établissements d'enseignement et de recherche français ou étrangers, des laboratoires publics ou privés. 


\title{
Temporal evolution of atrazine and metolachlor concentrations exported in runoff and subsurface water with vegetated filter strips
}

\author{
Emmanuelle Caron • Pierre Lafrance • \\ Jean-Christian Auclair
}

Accepted: 28 February 2012 / Published online: 27 March 2012

(C) INRA and Springer-Verlag, France 2012

\begin{abstract}
Metolachlor and atrazine are herbicides used in corn agriculture and detected in surface- and groundwater. Vegetated filters reduce masses of herbicides in runoff, but less attention has been given to their impact on degradation products and subsurface infiltrated water. The objective was to study the temporal evolution of dissolved metolachlor, atrazine and deethylatrazine concentrations in runoff and subsurface infiltrated water with two types of vegetated filters over 2 years for the first three rains following herbicide application. Runoff and subsurface infiltrated at $90-\mathrm{cm}$ water samples from 12 plots of $30 \times 5 \mathrm{~m}$ in a completely randomized block design of four replicates of three treatments-control without filter, 5-m-long grass filter, 5-m-long grass and tree filter were analysed using gas chromatography/mass spectrometry. Controls in runoff generally had the highest average atrazine, as high as $739 \mu \mathrm{g} \mathrm{L}^{-1}$, and metolachlor average concentrations, as high as $1,725 \mu \mathrm{g} \mathrm{L}^{-1}$. The first rain after application was mainly responsible for atrazine and metolachlor exports. Vegetated filters reduced concentrations of atrazine and metolachlor in runoff below their respective Canadian criterion of $1.8 \mu \mathrm{g} \mathrm{L}^{-1}$ for atrazine and $7.8 \mu \mathrm{g} \mathrm{L}^{-1}$ for metolachlor (provisory) (CCME 2002) for the protection of aquatic life when rain did not occur shortly after application. With the need to increase food production and agricultural yields to sustain the increasing world population came the need to develop efficient mitigation tools such as vegetated filter strips to reduce the ecotoxicologial impacts of pesticides. The present study is among the few that examined
\end{abstract}

E. Caron $\cdot$ P. Lafrance $(\triangle) \cdot$ J.-C. Auclair

Institut National de la Recherche Scientifique,

Centre ETE (INRS-ETE),

490, rue de la Couronne,

Québec, QC G1K 9A9, Canada

e-mail: pierre.lafrance@ete.inrs.ca herbicide degradation products and subsurface infiltrated water under filter strips in order to provide new knowledge on the relationship between herbicide loss pathways and the environmental benefits of these strips. Such knowledge will provide much needed information to modellers, decision makers, ecotoxicologists and agronomists involved in the regulation, design and implementation of vegetated filter strips for the protection of water quality.

Keywords Herbicide $\cdot$ Atrazine $\cdot$ Metolachlor .

Deethylatrazine $\cdot$ Buffer strips

\section{Abbreviations}

CCME Conseil Canadien des Ministres de l'Environnement

$K_{\mathrm{oc}} \quad$ Soil organic carbon distribution coefficient

$\mathrm{LC}_{50} \quad$ Median lethal concentration

a.i. Active ingredient

ANOVA Analysis of variance

\section{Introduction}

Metolachlor (2-chloro- $N$-(6-ethyl-o-tolyl)- $N$-[(1RS)-2-methoxy1-methylethyl]acetamide) and atrazine (6-chloro- $N 2$-ethyl- $N 4$ isopropyl-1,3,5-triazine-2,4-diamine) are two herbicides that are frequently detected in surface waters around the world. The maximum allowed concentration of atrazine for drinking water is $3 \mu \mathrm{g} \mathrm{L}^{-1}$ (annual average maximum) in the USA (US Environmental Protection Agency 1991). In Canada, the criterion for the protection of aquatic life from a chronic exposure to metolachlor is $7.8 \mu \mathrm{g} \mathrm{L}^{-1}$ (provisory), while it is $1.8 \mu \mathrm{g} \mathrm{L}^{-1}$ for atrazine (CCME) 2002). 
One of the main degradation products of atrazine is deethylatrazine (6-chloro-2- $N$-propan-2-yl-1,3,5-triazine-2,4diamine). Deethylatrazine has a greater mobility in soil than atrazine because of its lesser sorption and greater aqueous solubility (Table 1). Although it is not routinely included in monitoring studies, deethylatrazine has been detected in the Brévilles Spring in concentrations ranging from 0.55 to $1.05 \mu \mathrm{g} \mathrm{L}^{-1}$ (Barth et al. 2007). Few studies are available on the sensitivity of aquatic organisms to this chemical. RalstonHooper et al. (2009) determined that the $\mathrm{LC}_{50}$ (median lethal concentration) for an exposure of 21 days for the amphipod Diporeia spp. was $330 \mu \mathrm{g} \mathrm{L}^{-1}$ for deethylatrazine and $240 \mu \mathrm{g} \mathrm{L}^{-1}$ for atrazine, although stress possibly contributed in reducing the observed survival of Diporeia spp. in that study. Acute pre-natal exposure to a mixture of atrazine metabolites, including deethylatrazine, delayed the development of mammary glands in female Long-Evans rats (Enoch et al. 2007). The presence of deethylatrazine in mixture with atrazine and other similar chemicals is an issue of concern since Faust et al. (2001) were able to predict the toxicity of mixtures of similarly acting pesticides on the freshwater alga Scenedesmus vacuolatus using the concentration addition model.

Wauchope (1978) demonstrated that the first rain events occurring after herbicide application were mainly responsible for herbicide exports and that the shorter the delay between rain events and herbicide application, the greater were the observed herbicide exports. The reduction of pesticide masses in runoff using vegetated filter strips was the object of studies by Patty et al. (1997); Lafrance et al. (2001); Syversen and Bechmann (2004) and Caron et al. (2010), among others. The main attenuation mechanisms at play for herbicides in vegetated filter strips are infiltration, sediment deposition, sorption (Arora et al. 2010) and degradation. These mechanisms are influenced by the solubility of the studied chemical. Atrazine is mainly transported in dissolved phase due to its moderate solubility (Table 1). In their 2005 review on grass strips, Lacas et al. stressed the need for more studies concerned with the fate of degradation products in vegetated filter strips and the importance of subsurface infiltrated water concentrations of herbicides under vegetated filter strips.
Subsurface infiltration of water is an important process to consider since it influences the quality of groundwater, which is often used for human consumption. The unique subsurface infiltrated water sampling system used in the current study will enable determining herbicide concentrations, including a degradation product of atrazine, deethylatrazine, not only in runoff but also in subsurface infiltrated water right under the vegetated filter strips in agricultural plots under natural field conditions and climate.

Few studies looked at the possible influence of vegetated filter strips on dissolved concentrations of degradation products of herbicides (Lacas et al. 2005), and most of these studies were conducted in a laboratory. In a study on the impact of Buffalograss strips using simulated conditions on a $1 \times 3-\mathrm{m}$ plot in a clay soil in Texas, the trapping efficiency of the strips in runoff was greater for atrazine than for its metabolites, including deethylatrazine (Krutz et al. 2003a). In the same type of soil but under a mixed stand of Bermudagrass and Buffalograss, Krutz et al. (2003b) predicted, using batch equilibrium experiments, that vegetated filter strips would be able to delay atrazine transport to groundwater, but not that of deethylatrazine.

The objective of the present study was to determine the temporal evolution of dissolved metolachlor, atrazine and its metabolite deethylatrazine concentrations in runoff and subsurface infiltrated water as it occurs using two types of vegetated filter strips, grass or grass and tree for the first three rain events following the annual herbicide application in each of two study years under natural climatic conditions. This will provide for a better understanding of the impact of these types of vegetated filter strips on herbicide concentrations in subsurface infiltrated water and on metabolite concentrations in both runoff and subsurface infiltrated water. Additional information will be provided on the interannual variability of the trapping efficiency of vegetated filter strips. Finally, the current study will determine if the presence of vegetated filter strips could improve water quality from a toxicological point of view and if concentrations of deethylatrazine in mixtures with atrazine and their potential toxicological impacts are considerable or negligible under natural field conditions.

Table 1 Selected physicochemical properties of metolachlor, atrazine and deethylatrazine

\begin{tabular}{|c|c|c|c|c|}
\hline Property & Metolachlor & Atrazine & Deethylatrazine & References \\
\hline Molecular weight $\left(\mathrm{g} \mathrm{mol}^{-1}\right)$ & 283.8 & 215.7 & 187.6 & $\begin{array}{l}\text { Kegley et al. 2010; Worthing and Walker 1987; } \\
\text { Howard and Meylan } 1997\end{array}$ \\
\hline Solubility $\left(\mathrm{mg} \mathrm{L}^{-1}\right.$ in water at $\left.22^{\circ} \mathrm{C}\right)$ & 530 & 33 & 2700 & $\begin{array}{l}\text { Rice et al. } 2004 \text { for metolachlor and atrazine; } \\
\text { Vryzas et al. } 2007 \text { for DEA }\end{array}$ \\
\hline Log octanol to water partition coefficient & 3.4 & 2.7 & 1.5 & $\begin{array}{l}\text { FOOTPRINT } 2006 \text { for metolachlor and atrazine; } \\
\text { Finizio et al. } 1991 \text { for DEA }\end{array}$ \\
\hline $\begin{array}{l}\text { Organic carbon distribution coefficient } \\
\left(K_{\mathrm{oc}}\right)\left(\mathrm{mL} \mathrm{g}^{-1}\right)\end{array}$ & 120 & 100 & 72 & All from FOOTPRINT 2006 \\
\hline
\end{tabular}

References are presented in the same order than compounds 


\section{Material and methods}

\subsection{Experimental setup}

A completely randomized block design with four replicates of three treatments: control without filter strip, 5-m-long $\times 5-\mathrm{m}$ wide grass filter strip, 5-m-long $\times 5$-m-wide grass and tree filter strip, was setup at the Ferme expérimentale de l'Institut de Recherche et de Développement en Agroenvironnement inc. in St-Lambert-de-Lauzon, QC, Canada $\left(46^{\circ} 36.5^{\prime} \mathrm{N}\right.$, $71^{\circ} 10.5^{\prime} \mathrm{W}$ ) on a silty loam with a $3 \%$ slope (Fig. 1 ). We expect that the site was established on a homogeneous piece of land on the experimental farm. This was confirmed for the soil $(0-15 \mathrm{~cm})$ organic matter in the vegetated strips which showed little variation: median organic matter content was $3.2 \%$ in the grass filter strips and $3.3 \%$ in the grass and tree filter strips (Duchemin and Hogue 2009). Such a small
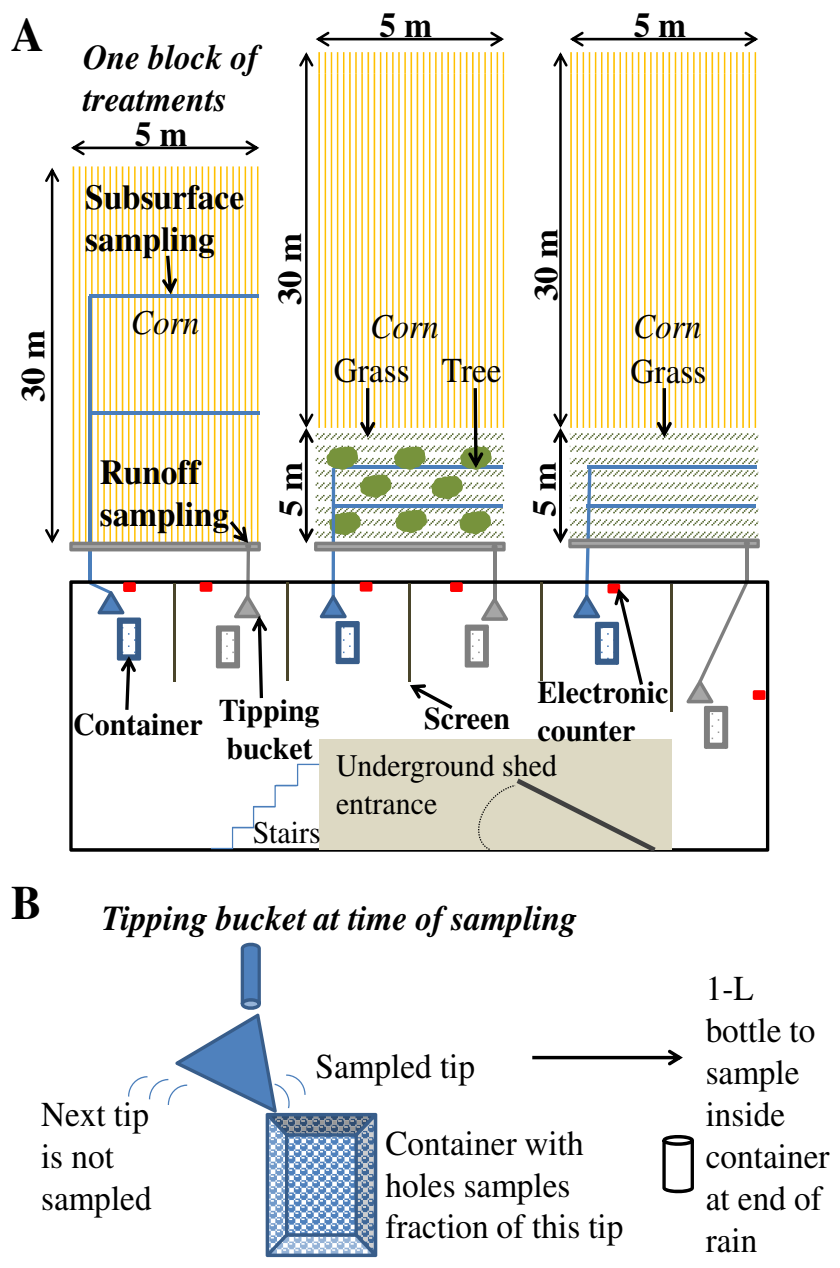

Fig. 1 Experimental setup in one block of treatment (a) and sampling device and procedure (b). Runoff and subsurface water from each plot are separately directed towards a tipping bucket, then towards a container and the sample is collected for analysis from this container by a 1 - $\mathrm{L}$ bottle at the end of the rain event variation is expected to have negligible effects on herbicide sorption. The grass mix was composed of $45 \%$ red fescue (Festuca rubra L.), 45\% white redtop (Agrostis alba L.) and $10 \%$ ryegrass (Lolium perenne L.). Eight hybrid poplars in an off-set position (Populus tricocharpa $\times$ Populus deltoids, 1 year old at the time of site establishment in November 2003), were added to this grass filter strip to create the grass and tree filter strip. Each plot of 5-m-wide $\times 30$-m-long was cultivated in corn (Zea mays L.), and plots were fertilized with swine manure at a rate of $40 \mathrm{t} \mathrm{ha}^{-1}$ at the end of May in 2004 and 2005 (Duchemin and Hogue 2009).

\subsection{Herbicide treatment and sample collection}

Herbicides were applied as a mixture of atrazine and metolachlor in a commercial formulation (Primextra II Magnum, active ingredients (a.i.) $0.31 \mathrm{~kg} \mathrm{~L}^{-1}$ atrazine and $0.40 \mathrm{~kg} \mathrm{~L}^{-1}$ metolachlor; Syngenta, Guelph, ON) on the entire cultivated surface at the recommended rate of $1.25 \mathrm{~kg} \mathrm{ha}^{-1}$ of a.i. for atrazine and $1.6 \mathrm{~kg} \mathrm{ha}^{-1}$ of a.i. for metolachlor on June 29 , 2004 and June 21, 2005. No herbicides had previously been applied on the plots. All surface runoff at the exit of the strips was collected by a gutter at the soil surface, while subsurface infiltrated water at $90-\mathrm{cm}$ deep under the filter strip treatments was collected through $10-\mathrm{cm}$ sampling drains. Volumes of runoff and subsurface infiltrated water were measured using calibrated 1-L specifically designed tipping buckets linked to an electronic counter. Tipping buckets collected one tip out of two and the container sampled a fraction of the sampled tip. Runoff and subsurface infiltrated water were collected for each plot in its respective container at the end of the rain event in a 1-L wide-mouth high-density polyethylene bottle (Nalgene, Rochester, New York) for the first three rain events after herbicide application in 2004 and 2005 (Fig. 1b). The water collection system had been installed and correctly tested in 2003. Plots were isolated from each other by ridges, and they were isolated from the rest of the site by a road to the west, a forest to the east, grass to the north and a drainage ditch to the south at $30 \mathrm{~m}$. The site was $3 \mathrm{~m}$ above the water line of that ditch. Therefore, the sampling system was at least $2 \mathrm{~m}$ higher than this water line. The site was also isolated from groundwater by a 1.3-m-deep tile drain which would have lowered the water table if it ever was to reach that point; therefore, no dilution of agrichemicals by groundwater occurred in the subsurface infiltrated water collection system.

\subsection{Herbicide analysis}

Water samples were kept in a cooler and brought to the laboratory where they were frozen before being processed for herbicide analysis. Water was double-filtered: first, it was vacuum filtered through $1.5-\mu \mathrm{m}$ glass fibre filters (Whatman, Piscataway, NJ), and then through $0.45-\mu \mathrm{m}$ 
(Magna Nylon; Osmonics, Minnetonka, MN) filters. A volume of $250 \mathrm{~mL}$ of water was extracted with a C-18 Environmental cartridge (Waters, Mississauga, $\mathrm{ON}$ ), eluted in ultra-pure Milli-Q water-saturated pesticide-grade ethyl acetate (Fisher Chemicals, Fair Lawn, NJ) and concentrated under 0 grade nitrogen to obtain a final volume of $1 \mathrm{~mL}$. The external standard was terbutryne (Chemservice, West Chester, PA), and standard recovery was good at $93 \%$ for all samples averaged over the six studied rain events. The internal standard was ametryne (Supelco, Oakville, ON). Analyses for metolachlor, atrazine and deethylatrazine were carried out using $1 \mu \mathrm{L}$ of the extract on a Clarus 500 gas chromatograph/ mass spectrometer (GC/MS; PerkinElmer, Waltham, MA). A Factor Four VF-5 ms, 30-m long, 0.25-mm internal diameter column with helium as carrier gas was used. Retention times were adjusted and a new calibration curve was made for each new batch of injections. Quality control for each series of 12 samples included a duplicate sample, an extraction blank, a fortified blank and a control sample made using commercial standards. Instrumental detection limits of the GC/MS were
0.007, 0.002 and $0.006 \mu \mathrm{g} \mathrm{mL}^{-1}$, respectively, for metolachlor, atrazine and deethylatrazine in pesticide-grade ethyl acetate. The calculated limits of quantification taking into account the concentration factor were: 0.03 , 0.008 and $0.024 \mu \mathrm{g} \mathrm{L}^{-1}$, respectively, for metolachlor, atrazine and deethylatrazine.

\subsection{Calculations and statistics}

Average concentrations were calculated using all the available replicates of each treatment for each rain event and for runoff and subsurface infiltrated water separately. In rare cases, concentrations below the instrument detection limit were neglected as they contain no numerical information. In addition, due to late precipitation (dry soils), there were some missing runoff samples in 2005.

The percentage of applied atrazine exported as deethylatrazine was calculated for each treatment, for each of runoff and subsurface infiltrated water and for each rain event by the following formula:

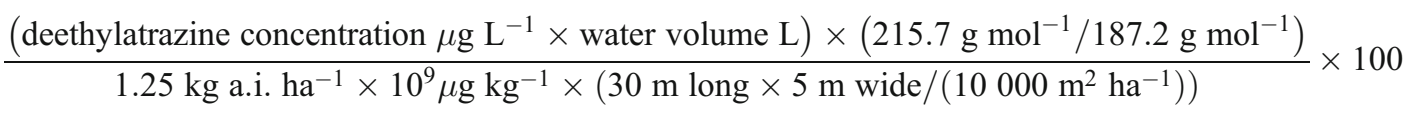

On a rain event basis, concentrations respected conditions of normality and equality of variances (Caron et al. 2010). There was no correlation $\left(p>0.05\right.$ and $R^{2}$ always below 0.05 with $n=53$ for atrazine and deethylatrazine and $n=48$ for metolachlor) between herbicide concentrations and runoff volumes for 2004 and 2005 (results not shown). The ultimate goal of the statistical analyses was to study the effect of the factor Day, which is the delay in days between annual herbicide application and rain event sampling, on metolachlor, atrazine and deethylatrazine concentrations. A one-way analysis of variance (ANOVA) using factor water, runoff or subsurface infiltrated water was performed in JMP 8.0 from SAS Institute on the entire dataset to determine how the data could be regrouped for the one-way ANOVA with factor Day. The chosen significance level for all statistical analyses was $p<0.05$. When a significant effect was found, the Tukey honest significant difference test was conducted for multiple comparisons. Concentrations were treated on a yearly basis because there were two herbicide applications, one in 2004 and one in 2005, as well as different weather conditions for each study year and because concentrations of metolachlor, atrazine and deethylatrazine were greater in 2004 than in 2005. Runoff or subsurface infiltrated water were treated separately for metolachlor and atrazine concentrations because they were significantly different. Due to an absence of runoff (dry soils), no analysis was conducted on runoff in 2005 for atrazine and metolachlor. For deethylatrazine, each study year was also treated separately, but runoff and subsurface infiltrated water were regrouped, to increase statistical power, since they were not significantly different.

\section{Results and discussion}

\subsection{Description of rain events}

No precipitation occurred during herbicide application in 2004, but rain was observed later on that day. Sampling dates, which generally occurred on the day following rain events, were June 30, 2004 after $15 \mathrm{~mm}$ of rain, July 2, 2004 after $15 \mathrm{~mm}$ of rain and July 9, 2004 after $45 \mathrm{~mm}$ of rain. These dates correspond to days 1, 3 and 10 after herbicide application. High volumes of water in runoff and subsurface infiltrated water were observed. In contrast, during 2005, the sampling dates occurred on July 11 after $49 \mathrm{~mm}$ of rain, July 15 after $19 \mathrm{~mm}$ of rain, and July 19 after $29 \mathrm{~mm}$ of rain. These dates correspond to days 20,24 and 27 after herbicide application; therefore, soil conditions were drier than 2004. 
3.2 Temporal evolution of metolachlor and atrazine concentrations

The high observed metolachlor concentrations are a result of (a) a greater application rate for metolachlor than atrazine and (b) the greater solubility of metolachlor compared with that of atrazine (Table 1). Average concentrations in runoff of metolachlor and atrazine generally decreased with time for all treatments in both study years, except on day 24 in 2005 (Fig. 2). Concentrations of atrazine and metolachlor were significantly $(p<0.05)$ higher on day 1 than on any other day in 2004 in runoff. In addition, metolachlor concentrations on day 3 were significantly $(p<0.05)$ higher than those on day 10. The importance of the first rain event for exported herbicide concentrations occurring after herbicide application had also been observed by Wauchope (1978) and Spencer and Cliath (1991). For all studied rain events in runoff, controls showed greater average metolachlor and atrazine concentrations than vegetated filter strips, grass or grass and tree. This difference was the most important, with $300 \mu \mathrm{g} \mathrm{L}^{-1}$ more exported in the control than vegetated filter strips, for the first rain in 2004 for metolachlor, and
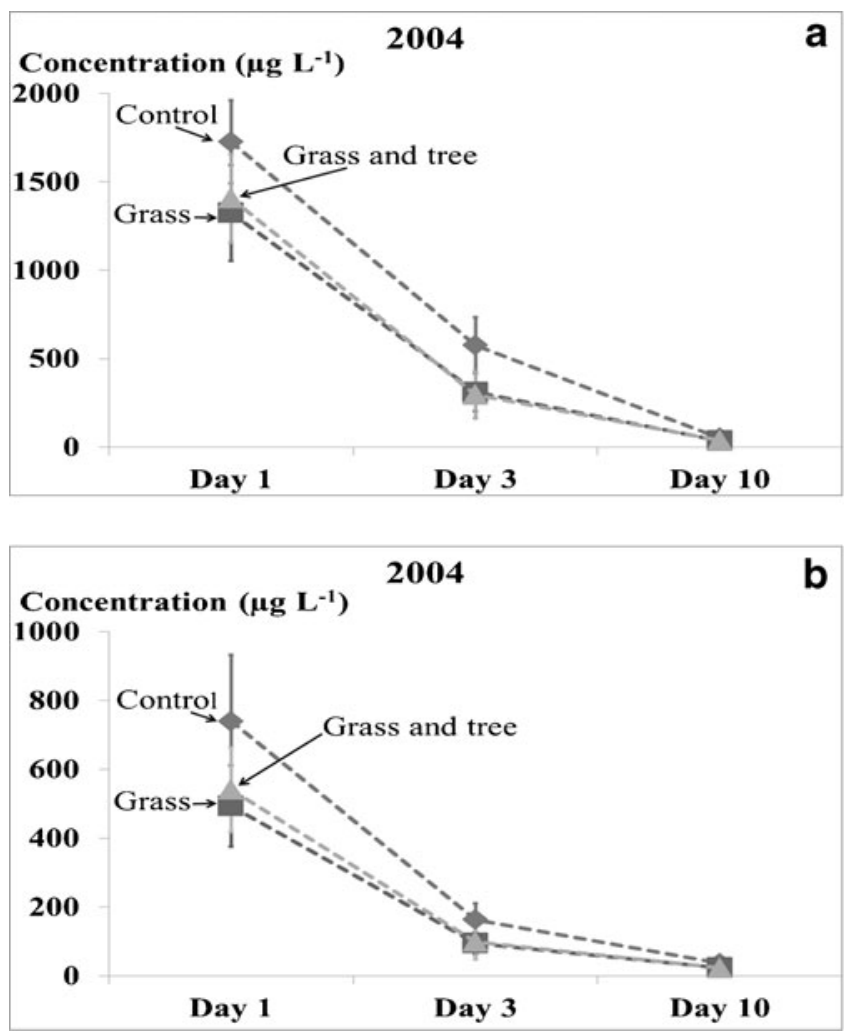

Fig. 2 Temporal evolution of a metolachlor in 2004, b atrazine in 2004 , c metolachlor in 2005 and $\mathbf{d}$ atrazine in 2005 dissolved concentrations in runoff for the control, grass and grass and tree filter strips. Error bars, one standard error. For 2004, error bars for day 10 are too small to be visible. Day is the number of days between herbicide
$200 \mu \mathrm{g} \mathrm{L}^{-1}$ for atrazine. No analysis was performed using factor Day in runoff in 2005 because of missing data.

For metolachlor and atrazine, concentrations in subsurface infiltrated water were significantly $(p<0.05)$ lesser than in runoff due to increased sorption and degradation as the compounds progressed towards the sampling depth of $90 \mathrm{~cm}$ (Fig. 3). As was the case for runoff, average metolachlor and atrazine concentrations in subsurface infiltrated water generally decreased with time in both study years since a delay between herbicide application and rain event favours soil sorption and degradation processes. In 2004, for both chemicals, concentrations measured in subsurface infiltrated water on day 1 were significantly $(p<0.05)$ higher than on other days of the study in 2004. In 2005, the effect of the factor Day was not significant $(p>0.05)$ since metolachlor and atrazine concentrations in subsurface infiltrated water were already low due to the long delay between herbicide and rain events.

\subsection{Temporal evolution of deethylatrazine concentrations}

The temporal evolution of deethylatrazine was treated separately from that of atrazine because the fate of atrazine is
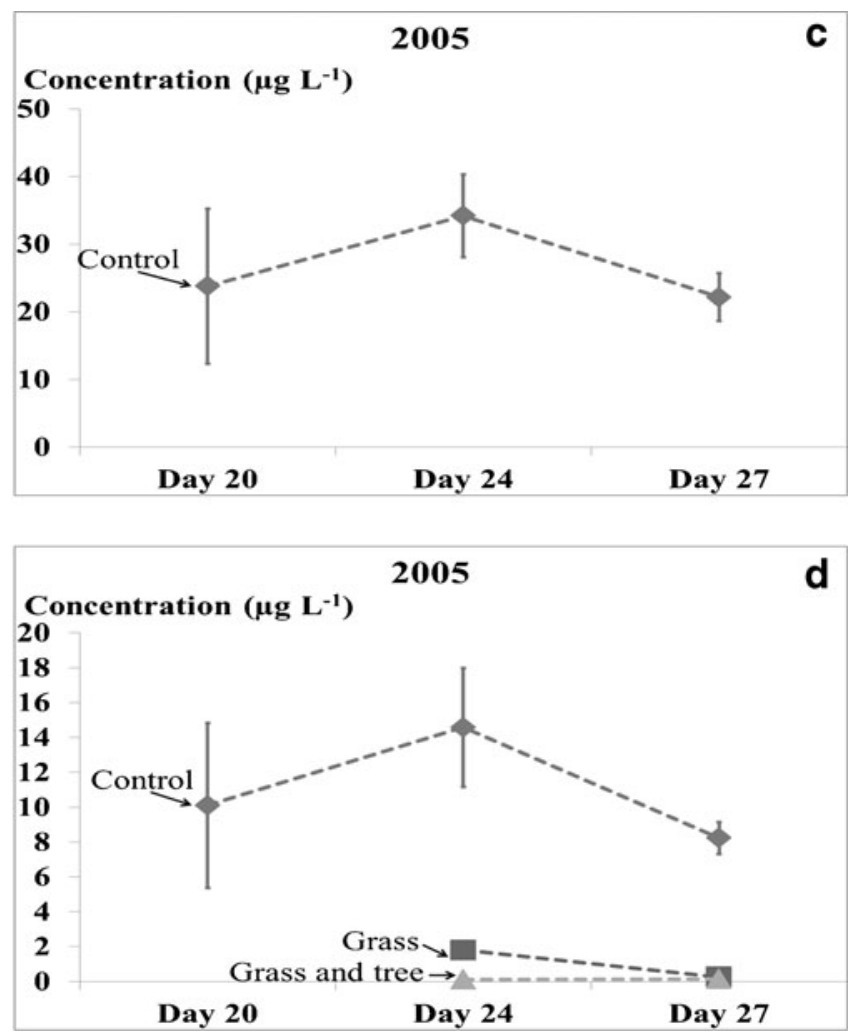

application and sampling. In 2004, a rapid decrease of exported concentrations occurred over time. Most of the herbicide losses occurred at the first rain event following herbicide application. Concentrations for the control were greater than those for grass or grass and tree filter strips, showing the efficiency of vegetated filter strips 

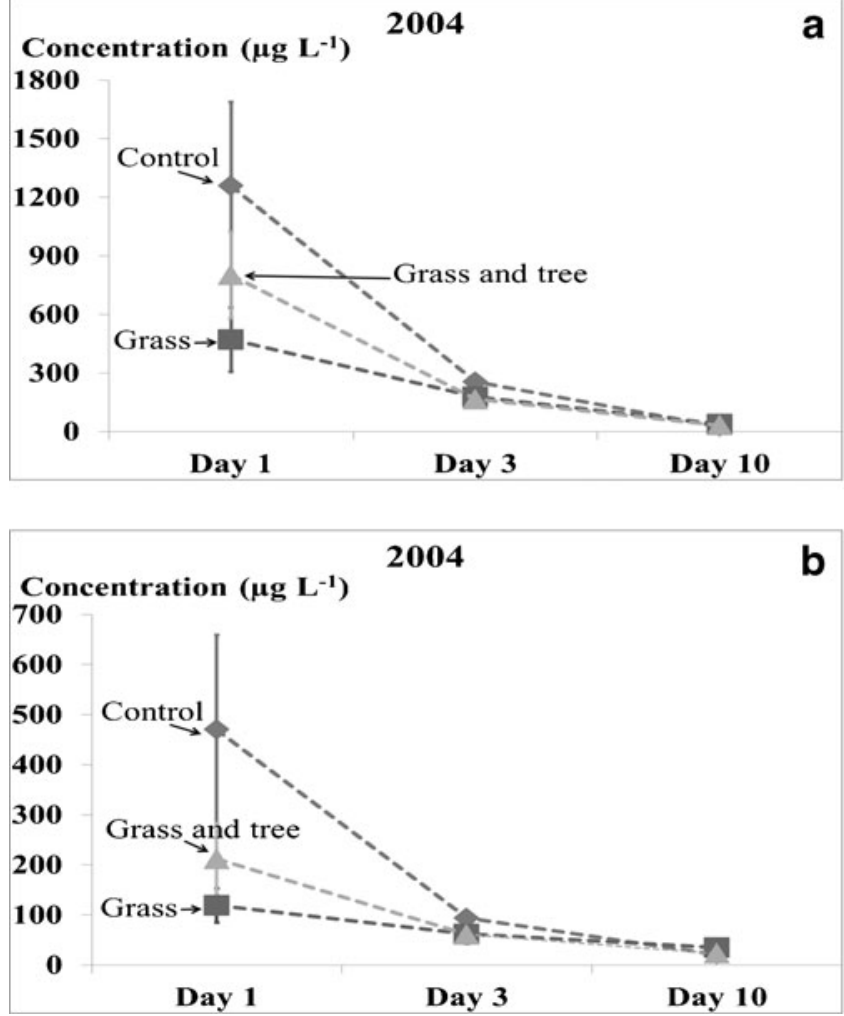

Fig. 3 Temporal evolution of a metolachlor in 2004, b atrazine in 2004, c metolachlor in 2005 and $\mathbf{d}$ atrazine in 2005 dissolved concentrations in subsurface infiltrated water for the control, grass and grass and tree filter strips. Error bars, one standard error. For 2004, error bars for day 10 are too small to be visible. Day is the number of days

governed mainly by two processes, atrazine sorption, which influences its transport and its availability for degradation, such as is the case for other herbicides (Ogram et al. 1985), and atrazine degradation to deethylatrazine, while concentrations of deethylatrazine are dependant first on atrazine degradation to deethylatrazine and sorption of atrazine, and second, on deethylatrazine's high solubility and its own degradation rate. In addition, as already mentioned in section 2.4, atrazine concentrations in runoff were significantly $(p<0.05)$ greater than in subsurface infiltrated water, while there was no significant difference $(p>0.05)$ between runoff and subsurface infiltrated water for deethylatrazine.

For deethylatrazine, in runoff, controls showed slightly greater average concentrations than vegetated filter strips; this difference was the most important for the last rain event in 2005 , with $1.6 \mu \mathrm{g} \mathrm{L}^{-1}$ more exported in the control than in the grass filter strip. In both study years, deethylatrazine peaks in runoff from controls were observed on the second rain event (Fig. 4a, b). In 2005, for the vegetated filters, no samples were obtained on day 20 .

In 2004, when considering runoff and subsurface infiltrated water together, deethylatrazine concentrations significantly $(p<0.05)$ decreased in the order of day $3 \geq$ day $1 \geq$ day 10. Therefore, this delay of 3 days between herbicide
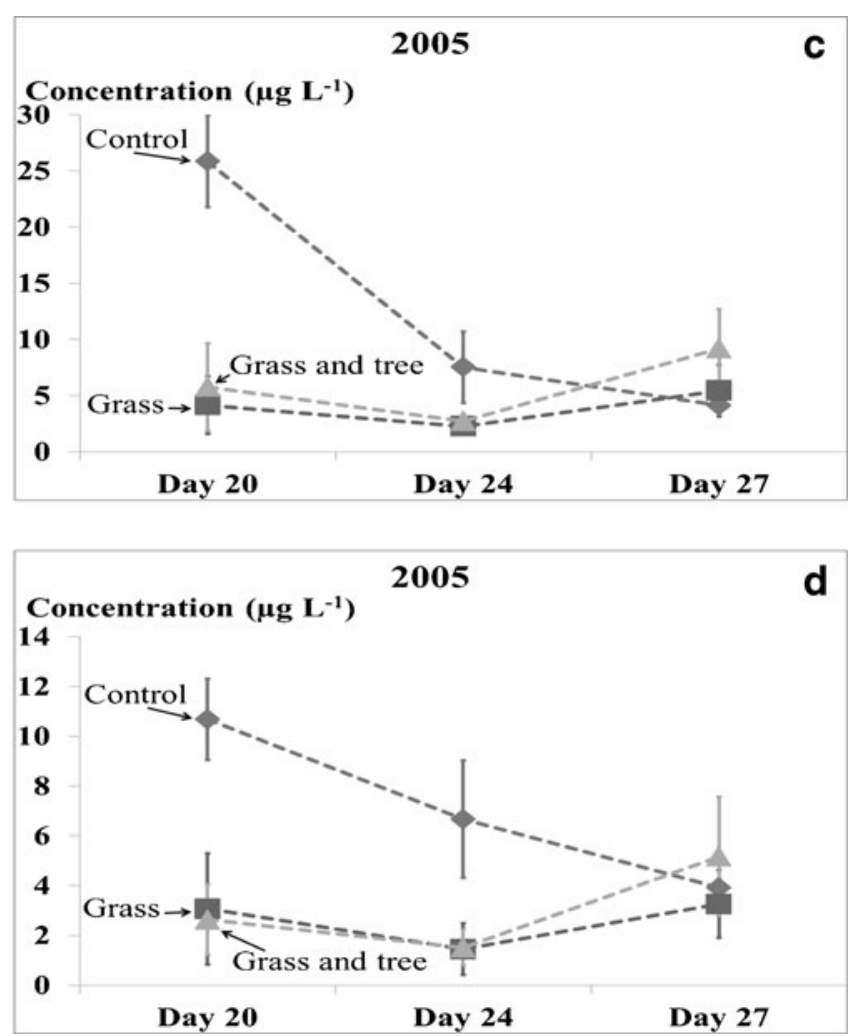

between herbicide application and sampling. Temporal evolution of herbicides in subsurface infiltrated water showed a pattern similar to the ones in runoff in 2004. Concentrations in subsurface infiltrated water were lesser than in runoff. Grass filter strips were efficient at attenuating herbicide concentrations

application and rain event would represent the optimum between degradation of atrazine to deethylatrazine, deethylatrazine degradation, sorption of both these compounds and export as influenced by climate and the presence of vegetated filter strips in the studied system in 2004. In 2001, Bayless measured peaks of deethylatrazine between 30 and 60 days later than the atrazine peak in the vadose zone for a study conducted in Hancock County, Indiana (Bayless 2001). In 1994, Thurman et al. concluded that the optimum period for peak concentrations of deethylatrazine was between 10 and 20 days in runoff from field plots in Kansas (Thurman et al. 1994). In 2005, when considering runoff and subsurface infiltrated water together, there was no significant effect of Day $(p>0.05)$ on deethylatrazine concentrations because concentrations were low and possibly, the optimum period for deethylatrazine export had already passed when the first rain event occurred 20 days after herbicide application.

A complex combination of factors and their interactions can potentially determine exported concentrations of deethylatrazine in subsurface infiltrated water (Fig. 4c, d). These concentrations are not only the result of the presence of vegetated filter strips but are also dependant among other factors on time between atrazine application and rain events 


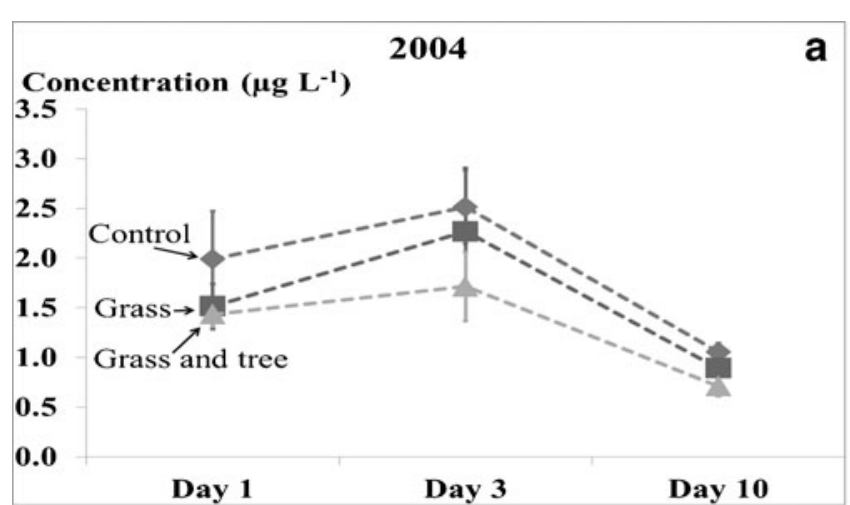

a

Day 1

Day 3

2005

Concentration $\left(\mu \mathrm{g} \mathrm{L}^{-1}\right)$

2.5

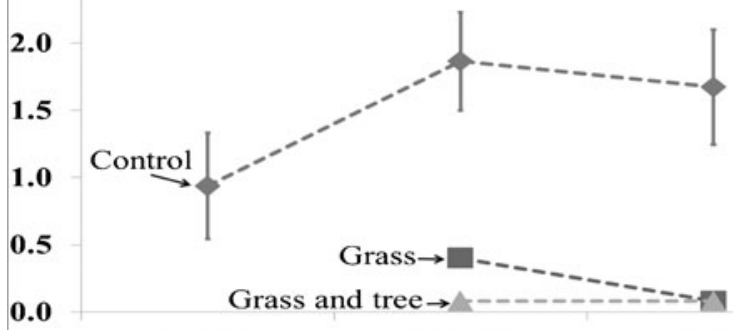

Day 20

b

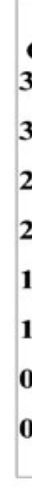

3.5

3.5

3.0

2.0

2.0

1.5

1.0

0.5

0.0

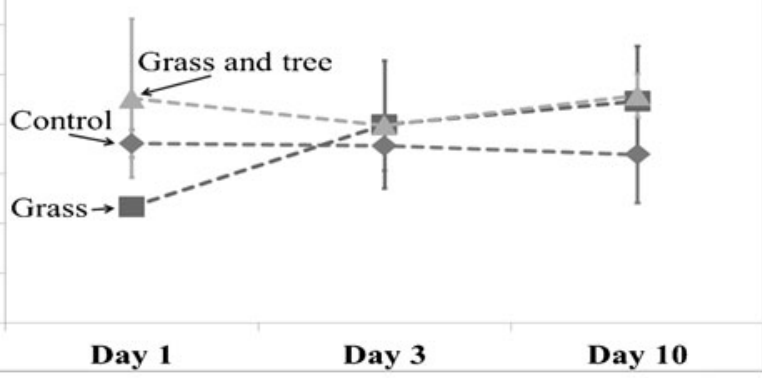

Concentration $\left(\mu \mathrm{g} \mathrm{L}^{-1}\right)$

3.0

2.5

2.0

1.5

1.5

1.0

0.5

0.0

Day 20

Day 24

Day 27

runoff in 2004, deethylatrazine concentrations increased from herbicide application to the second rain event. This behaviour was also observed for the control in subsurface infiltrated water in 2005 but not in 2004

case scenario in which for example a ditch would be located at the end of a field, which is often the case in Quebec, without dilution. Upstream sections of water courses are usually more concentrated in herbicides than downstream sections due to the river dilution effect (Hua et al. 2006). All 2004 average dissolved concentrations in runoff and subsurface infiltrated water exceeded the Canadian criteria for the protection of aquatic life (chronic) for metolachlor and atrazine. In 2005, in runoff, the controls exceeded the criteria for both metolachlor and atrazine, while the presence of vegetated filter strips, when samples could be collected, reduced concentrations below or at the criteria for both chemicals. In subsurface infiltrated water, for metolachlor, average concentrations in the control on day 20 and the grass and tree filter strip on day 27 exceeded the criterion, while for atrazine, only the vegetated filter strips on day 24 in 2005 respected the criterion. Therefore, in 2005, when there was a long lag time between herbicide application and the first rain event, vegetated filter strips were most of the time able to reduce exported concentrations in runoff below the criteria for the protection of aquatic life of both studied chemicals. Huber (1993) as well as Solomon et al. (1996) established a no observable effect concentration of $20 \mu \mathrm{g} \mathrm{L}{ }^{-1}$ for

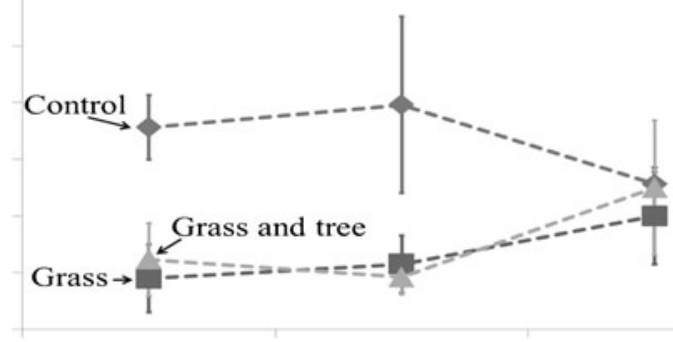

Average measured concentrations were compared against water quality criteria. It should be noted that this comparison using the present sampling design represents a worst-

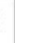

Fig. 4 Temporal evolution of deethylatrazine dissolved concentrations 2004 and $\mathbf{d}$ subsurface infiltrated water in 2005 for the control, grass the number of days between herbicide application and sampling. In

3.4 Comparison of measured dissolved herbicide concentrations with water quality criteria 
atrazine in aquatic ecosystems. All average concentrations for 2004 exceeded this concentration while none of the 2005 did. All the collected samples in the present study had deethylatrazine concentrations that were at least a hundred times less than the $\mathrm{LC}_{50}$ for an exposure of 21 days to deethylatrazine in Diporeia spp. as measured by Ralston-Hooper et al. (2009); therefore, it is unlikely that deethylatrazine could threaten species such as Diporeia in aquatic ecosystems. However, it is important to remember that monitoring periods in the current study were relatively short, 10 days or less, which did not provide for a lot of time for atrazine degradation to deethylatrazine between rain events.

\subsection{Proportion of applied atrazine exported as deethylatrazine}

The temporal evolution of the proportion of the applied mass of atrazine exported as deethylatrazine (result not shown) indicates that the greatest proportion was observed on day 10 in 2004 for the control, while the lowest proportion was obtained on the same day in subsurface infiltrated water for all treatments. The proportion of applied atrazine exported as deethylatrazine was greater in the control treatment than in other treatments for each rain event in runoff in 2004 and 2005, which proves the ability of vegetated filter strips to reduce deethylatrazine concentrations in runoff. In subsurface infiltrated water in 2004 , this proportion was generally greater in the vegetated filter strips, either grass or grass and tree, than in the control treatment. It is possible that, by increasing infiltration and degradation of atrazine to deethylatrazine in the root zone, vegetated filter strips contributed to this increased proportion of applied atrazine exported as deethylatrazine in subsurface infiltrated water. For the current experimental field conditions, in all cases, the proportion of applied atrazine exported as deethylatrazine was low and was always lesser or equal to $0.014 \%$. The monitoring periods in this study were very short, 10 days in 2004 and 27 days in 2005. It is therefore unlikely, as observed, that deethylatrazine concentrations produced from a rain event to the other, in 3 to 7 days, would contribute to a great extent in increasing the toxicity of an herbicide mixture containing atrazine under these conditions. Results would have been different if the monitoring period would have spanned on the entire growing season or longer. Nevertheless, the current results showed that the appearance of deethylatrazine in runoff and subsurface infiltration water occurred shortly after atrazine application.

\section{Conclusion}

The present study is among the few to have examined the influence of herbicide loss pathways on their concentrations and temporal variations using two types of vegetated filter strips. The first rain following herbicide application plays a key role in the exported concentrations of atrazine and metolachlor. The closer this rain was from time of herbicide application, the greater the measured concentrations of parent compounds were. In 2004, when the first sampling took place on the day following application, metolachlor concentrations as high as $1,725 \mu \mathrm{g} \mathrm{L}^{-1}$ and atrazine concentrations of $739 \mu \mathrm{g} \mathrm{L}^{-1}$ were observed in runoff from the control treatment. In the mentioned conditions, parent compound concentrations in the control on the second rain event, 3 days after herbicide application, were equal to a third or less of what they were at the first rain event. In addition, deethylatrazine showed exportation peaks in runoff at the second rain event after application. Herbicide concentrations were reduced by the presence of vegetated filter strips and were lesser in subsurface infiltrated water than in runoff. Deethylatrazine concentrations never exceeded $2.6 \mu \mathrm{g} \mathrm{L}^{-1}$ during the short monitored periods. Nevertheless, its quick appearance suggests that its ecotoxicological impact should be studied considering an entire growing season. Vegetated filter strips were able to reduce runoff concentrations of atrazine and metolachlor below their respective Canadian criterion for the protection of aquatic life (chronic), which are 7.8 (provisory) and $1.8 \mu \mathrm{g} \mathrm{L}^{-1}$, respectively, for metolachlor and atrazine, if no rain occurred shortly after herbicide application, such as in 2005 when the first rain occurred 20 days after application. Mitigation tools, such as vegetated filter strips, are needed and are an efficient barrier to protect surface water from contamination by herbicides, and the new knowledge from the current and other future studies will be helpful for their optimum design and implementation in the field. Also, taking into account exportation pathways and the type of vegetated filter strips will help to properly estimate their efficiency and also to interpret associated water quality criteria.

Acknowledgments We thank Mr. Marc Duchemin. We also thank the INRS-ETE and IRDA laboratory and field technicians for their help. We acknowledge the financial support of the Natural Sciences and Engineering Research Council of Canada (NSERC) for this study on the fate of herbicides in agro-ecosystems.

\section{References}

Arora K, Mickelson SK, Helmers MJ, Baker JL (2010) Review of pesticide retention processes occurring in buffer strips receiving agricultural runoff. J Am Water Resour Assoc 46(3):618-647. doi:10.1111/1.1752-1688.2010.00438.x

Barth JAC, Steidle D, Kuntz D, Gocht T, Mouvet C, von Tümpling W, Lobe I, Langenhoff A, Albrechtsen H-J, Janniche GS, Morasch B, Hunkeler D, Grathwohl P (2007) Deposition, persistence and turnover of pollutants: first results from the EU project AquaTerra 
for selected river basins and aquifers. Sci Total Environ 376:4050. doi:10.1016/j.scitotenv.2007.01.065

Bayless ER (2001) Atrazine retention and degradation in the vadose zone at a till plain site in Indiana. Ground Water 39(2):169-180. doi:10.1111/j.1745-6584.2001.tb02298.x

Caron E, Lafrance P, Auclair JC, Duchemin M (2010) Impact of grass and grass with poplar buffer strips on atrazine and metolachlor losses in surface runoff and subsurface infiltration from agricultural plots. J Environ Qual 39:617-629. doi:10.2134/jeq2009.0041

Conseil Canadien des Ministres de l'Environnement (CCME) (2002) Recommandations Canadiennes pour la qualité de l'environnement, updated 2002. le Conseil, Winnipeg

Duchemin M, Hogue R (2009) Reduction in agricultural non-point source pollution in the first year following establishment of an integrated grass/tree filter strip system in southern Quebec (Canada). Agric Ecosyst Environ 131:85-97. doi:10.1016/j.agee.2008.10.005

Enoch RR, Stanko JP, Greiner SN, Youngblood GL, Rayner JL, Fenton SE (2007) Mammary gland development as a sensitive end point after acute prenatal exposure to an atrazine metabolite mixture in female Long-Evans rats. Environ Health Perspect 115(4):541547. doi:10.1289/ehp. 9612

Faust M, Altenburger R, Backhaus T, Blanck H, Boedeker W, Gramatica P, Hamer V, Scholze M, Vighi M, Grimme L (2001) Predicting the joint algal toxicity of multi-component $s$-triazine mixtures at loweffect concentrations of individual toxicants. Aquat Toxicol 56:1332. doi:10.1016/S0166-445X(01)00187-4

Finizio A, Diguardo A, Arnoldi A, Vighi M, Fanelli R (1991) Different approaches for the evaluation of Kow for s-triazine herbicides. Chemosphere 23:801-812. doi:10.1016/0045-6535(91)90084-Q

FOOTPRINT (2006) The FOOTPRINT Pesticide Properties DataBase. Database collated by the University of Hertfordshire as part of the EU-funded FOOTPRINT project (FP6-SSP-022704). http:// www.eu-footprint.org/ppdb.html. Accessed February 2012

Howard PH, Meylan WM (1997) Handbook of physical properties of organic chemicals. CRC Press Inc, Lewis Publishers, Boca Raton

Hua WY, Bennett ER, Maio XS, Metcalfe CD, Letcher RJ (2006) Seasonality effects on pharmaceuticals and s-triazine herbicides in wastewater effluent and subsurface water from the Canadian side of the upper Detroit River. Environ Toxicol Chem 25 (9):2356-2365. doi:10.1897/05-571R.1

Huber W (1993) Ecotoxicological relevance of atrazine in aquatic systems. Environ Toxicol Chem 12:1865-1881

Kegley SE, Hill BR, Orme S, Choi AH (2010) PAN Pesticide Database, Pesticide Action Network, North America, San Francisco, CA, http: www.pesticideinfo.org. Accessed February 2012

Krutz LJ, Senseman SA, Dozier MC, Hoffman DW, Tierney DP (2003a) Infiltration and adsorption of dissolved atrazine and atrazine metabolites in Buffalograss filter strips. J Environ Qual 32:2319-2324

Krutz LJ, Senseman SA, McInnes KJ, Zuberer DA, Tierney DP (2003b) Adsorption and desorption of atrazine, desethylatrazine, deisopropylatrazine, and hydroxyatrazine in vegetated filter strip and cultivated soil. J Agric Food Chem 51(25):7379-7384. doi:10.1021/jf0348572

Lacas JG, Voltz M, Gouy V, Carluer N, Gril JJ (2005) Using grassed strips to limit pesticide transfer to surface water: a review. Agron Sustain Dev 25:253-266. doi:10.1051/agro:2005001

Lafrance P, Guibaud G, Bernard C (2001) Rendement de zones tampon herbacées pour limiter les pertes d'herbicides en phase dissoute par ruissellement de surface. In Actes du $30^{\text {ième }}$ Congrès du Groupe Français des Pesticides, Reims, May 29th-31st 2000

Ogram AV, Jessup RE, Ou LT, Rao PSC (1985) Effects of sorption on biological degradation rates of (2,4-dichlorophenoxy) acetic acid in soils. Appl Environ Microbiol 49:582-587

Patty L, Réal B, Gril JJ (1997) The use of grassed buffer strips to remove pesticides, nitrate and soluble phosphorus compounds from runoff water. Pestic Sci 49:243-251

Ralston-Hooper K, Hardy J, Hahn L, Ochoa-Acuña H, Lee LS, Mollenhauer R, Sepúlveda MS (2009) Acute and chronic toxicity of atrazine and its metabolites deethylatrazine and deisopropylatrazine on aquatic organisms. Ecotoxicology 18:899-905. doi:10.1007/s10646-009-0351-0

Rice PJ, Anderson TA, Coats JR (2004) Effect of sediment on the fate of metolachlor and atrazine in surface water. Environ Toxicol Chem 23:1145-1155. doi:10.1897/03-110

Solomon KR, Baker DB, Richards RP, Dixon KR, Klaine SJ, La Point TW, Kendall RJ, Weisskoff CP, Giddings JM, Giesy JP, Hall LW Jr, Williams WM (1996) Ecological risk assessment of atrazine in North American surface waters. Environ Toxicol Chem 15(1):3176.

Spencer WF, Cliath MM (1991) Pesticide losses in surface runoff from irrigated fields. In: Pawlowsi L et al (eds) Chemistry for the protection of the environment. Plenum Press, New York, pp 277-289

Syversen N, Bechmann M (2004) Vegetative buffer zones as pesticide filters for simulated surface runoff. Ecol Eng 22:175-184. doi:10.1016/j.ecoleng.2004.05.002

Thurman EM, Meyer MT, Mills MS, Zimmerman LR, Perry CA (1994) Formation and transport of deethylatrazine and deisopropylatrazine in surface water. Environ Sci Technol 28:2207-2277. doi:10.1021/es00062a010

U.S. Environmental Protection Agency (1991) Fed Regist 56:3552

Vryzas Z, Papadopoulou-Mourdikou E, Soulios G, Prodomou K (2007) Kinetics and adsorption of metolachlor and atrazine and the conversion products (deethylatrazine, deisopropylatrazine, hydroxyatrazine) in the soil profile of a river basin. Eur J Soil Sci 58:1186-1199. doi:10.1111/j.1365-2389.2007.00913.x

Wauchope RD (1978) The content of surface water draining from agricultural fields - a review. J Environ Qual 7:459-472

Worthing CR, Walker SB (eds) (1987) The pesticide manual: a world compendium, 8th edn. Thornton Heath, British Crop Protection Council 